\title{
Bentuk Penyajian Kesenian Senjang dalam Konteks Acara Seremonial di Kota Sekayu
}

\author{
Irfan Kurniawan $^{1)}$, Juli Saputra ${ }^{2)}$ \\ ${ }^{1), 2)}$ Program Studi Pendidikan Seni Pertunjukan, Universitas PGRI Palembang \\ Email : irfan.kwn@gmail.com ${ }^{l)}$
}

\begin{abstract}
This research is a descriptive study of the phenomenon of Senjang art performance in the context of ceremonial events in the community of Sekayu city. This study used a qualitative approach, with data collection carried out by observation, interviews, and documentation, and data presentation techniques in the form of analytical descriptive writing. The results of this study are in the form of descriptions of the development of Senjang art in the city of Sekayu, and textual descriptions of the presentation of Senjang performances which include; the composition of the presentation of Senjang art, aspects of Senjang literary text, transcription of vocal music melodies, transcription of the main melody form of the musical instruments of Senjang, aspects of the players, the audience, and the place of the performance. Senjang is one of the traditional arts that has developed in Musi Banyuasin district, especially the city of Sekayu. Senjang is an oral literature of the type of pantun and talibun which in its presentation is combined with music and dance. This art has been inherited from generation to generation for a long time by the Musi Banyuasin community, especially the city of Sekayu. Senjang art initially only developed in Sungai Keruh sub-district, but over time this art began to develop in other areas around it, including in Babat Toman sub-district, Sanga Desa sub-district, and Sekayu district. In terms of the performance, Senjang is presented by telling rhymes spontaneously either singly (one person) or spoken by two people (usually in pairs) in an integrated manner, and accompanied by music. The accompaniment music in Senjang presentation usually uses a single organ, and there are some who use a single guitar, with the playing of short melodies that are repeated. In its presentation, the Senjang vocal music speech with accompanying musical instruments is not played simultaneously, but is played alternately.
\end{abstract}

Keyword: Presentation Form, Senjang, Sekayu City

\begin{abstract}
ABSTRAK
Penelitian ini merupakan penelitian deskriptif terhadap fenomena pagelaran seni senjang dalam konteks acara seremonial masyarakat kota Sekayu. Penelitian ini menggunakan pendekatan kualitatif, dengan pengumpulan data dilakukan dengan observasi, wawancara, dan dokumentasi, serta teknik penyajian data berupa penulisan deskriptif analitik. Hasil penelitian ini berupa deskripsi perkembangan seni senjang di kota sekayu, dan deskripsi tekstual penyajian pertunjukan senjang yang meliputi; komposisi penyajian seni senjang, aspek teks sastra senjang, transkripsi melodi musik vokal, transkripsi bentuk melodi utama alat musik senjang, aspek pemain, penonton, dan tempat pertunjukan. Senjang merupakan salah satu kesenian tradisional yang berkembang di kabupaten Musi Banyuasin khususnya kota Sekayu. Senjang adalah sastra lisan jenis pantun dan talibun yang yang dalam penyajianya dipadukan dengan musik dan tarian. Kesenian ini telah diwarisi secara turun temurun sejak lama oleh masyarakat Musi Banyuasin khususnya kota Sekayu. Kesenian Senjang awalnya hanya berkembang kecamatan Sungai Keruh, namun seiring berjalanya waktu kesenian ini mulai berkembang kedaerah lain disekitarnya, antara lain di kecamatan Babat Toman, Kecamatan Sanga Desa, dan Kecamatan Sekayu. Dari segi pertunjukannya, Senjang di sajikan dengan menuturkan pantun secara spontan baik secara tunggal (satu orang) maupun di tuturkan oleh dua orang (biasanya berpasangan) secara bersautan, dan diiringi oleh musik. Musik pengiring dalam penyajian Senjang biasanya menggunakan orgen tunggal, dan ada beberapa yang menggunakan gitar tunggal, dengan permainan melodi-melodi pendek yang di ulang-ulang. Dalam penyajianya tuturan musik vokal Senjang dengan instrumen musik pengiring tidak dimainkan secara bersamaan, akan tetapi dimainkan secara bergantian.
\end{abstract}

Kata Kunci : Bentuk Penyajian, Senjang, Kota Sekayu 


\section{Pendahuluan}

Senjang merupakan salah satu kesenian tradisional yang berkembang di kabupaten Musi Banyuasin khususnya kota Sekayu. Senjang adalah sastra lisan jenis pantun dan talibun yang yang dalam penyajianya dipadukan dengan musik dan tarian. Kesenian ini telah diwarisi secara turun temurun sejak lama oleh masyarakat Musi Banyuasin khususnya kota Sekayu. Kesenian Senjang awalnya hanya berkembang kecamatan Sungai Keruh, namun seiring berjalanya waktu kesenian ini mulai berkembang kedaerah lain disekitarnya, antara lain di kecamatan Babat Toman, Kecamatan Sanga Desa, dan Kecamatan Sekayu.

Menurut Ghafar banyak jenis sastra lisan yang terdapat dalam masyarakat musi diantaranya adalah jampi, nyambai, renggonang, andai-andai, tenggutengguan, dan Senjang. Sastra lisan Musi berkaitan dengan adat istiadat masyarakat Musi: Kaitan itu terlihat dalam upacara-upacara tradisional masyarakat Musi. Sastra lisan Senjang, misalnya, merupakan jenis sastra yang bersifat serimonial, yang digunakan pada waktu pesta perkawinan. Di dalam Senjang, kedua orang gadis berbalas-pantun sambil menari. Pesta perkawinan itu dianggap belum sempuna tanpa menggunakan Senjang (Ghafar: 1989: 11-12).

Dari segi pertunjukannya, Senjang di sajikan dengan menuturkan pantun secara spontan baik secara tunggal (satu orang) maupun di tuturkan oleh dua orang (biasanya berpasangan) secara bersautan, dan diiringi oleh musik. Musik pengiring dalam penyajian Senjang biasanya menggunakan orgen tunggal, dan ada beberapa yang menggunakan gitar tunggal, dengan permainan melodi-melodi pendek yang di ulang-ulang. Dalam penyajianya tuturan musik vokal Senjang dengan instrumen musik pengiring tidak dimainkan secara bersamaan, akan tetapi dimainkan secara bergantian. Pertunjukan diawali dengan permainan melodi instrumen musik, ketika instrument musik berhenti, baru masuk tuturan vokal pantun Senjang, dan ketika tuturan vokal Senjang berhenti, permainan melodi musik kembali dimainkan, dan begitu seterusnya secara bergantian sampai pertunjukan Senjang selesai.

Berdasarkan wawancara Sukma dengan Abdul Malik salah satu pemusik jidor, menjelaskan Pada awalnya, Senjang ditampilkan tanpa disertai oleh instrumen musik, kemudian disertai musik tradisional setempat yang sangat sederhana dan terbuat dari bahan alam. Seiring perkembangan waktu dan untuk pemanis tampilan munculah musik instrumen Senjang, yaitu seperangkat Jidor yang mulai ada sekitar tahun 1950-an. Kala itu Jidor dimainkan oleh 14 orang pemain dan delapan jenis alat musik. Kedelapan alat musik itu terdiri atas: dua buah terompet, sebuah jidor, sebuah tambur/senar drum, dua buah klarinet, dua buah saxophone tenor, dua buah saxophone alto, sebuah kontra bass, dan tiga buah alto horn (Sukma, 2015: 2).

Kesenian Senjang merupakan kesenian yang sangat eksis dan sangat di minati oleh masyarakat Sekayu saat ini. Kesenian ini sekarang tidak hanya digunakan pada acara perkawinan saja, akan tetapi juga pada acara ceremonial lainya di Sekayu seperti acara peresmian lembaga, penyambutan tamu, HUT RI, Festival budaya, kampanye politik, dan acara hiburan lainya. Bagi masyarakat Sekayu Senjang berfungsi sebagai media komunikasi sosial, seperti penyampaian aspirasi dan pesan-pesan yang berisikan nasehat, kritik, pendidikan, dan ungkapan kegembiraan. Bahkan Bagi masyarakat Sekayu suatu acara dirasa tidak lengkap jika tidak menampilkan kesenian Senjang.

Perkembangan kesenian Senjang saat ini di juga dukung oleh peran pemerintah Musi Banyuasin dalam mempromosikan seni budaya daerah, salah satunya dengan mengadakan festival "Randik" yang diadakan setiap tahunnya, festival ini memperkenalkan seni budaya yang ada di Musi Banyuasin seperti tari, musik, pakaian adat, kuliner, dan kesenian Senjang. Salah satu kegiatan dari festifal randik adalah diadakanya lomba Senjang sekabupaten Musi Banyuasin. Sehingga banyak kelompok dan sanggar seni di berbagai kecamatan di musi banyuasin yang melestarikan kesenian Senjang.

Berdasarkan fenomena kesenian Senjang yang telah diuraikan di atas tentunya banyak hal menarik yang perlu dikaji, namun pada kesempatan ini pembahasan artikel penelitian ini difokuskan pada bentuk penyajian seni pertunjukan Senjang di kota Sekayu yang terkait dengan aspek dan struktur penyajian kesenian Senjang.

Dalam penelitian ini, penulis menggunakan metode kualitatif sebagai salah satu pendekatan yang relevan untuk membantu membahas permasalahan penelitian dan menghasilkan data deskriptif berupa kata-kata tertulis atau lisan dari orang-orang dan perilaku yang dapat diamati (Dalam Maleong, 2000: 3).

Teknik penyajian dalam bentuk tulisan adalah deskriptif analitik. Dengan menggunakan metode ini hasil penelitian dideskripsikan dan dianalisis, yakni deskripsi tekstual berupa susunan pertunjukan, transkripsi musik instrumen dan musik vokal, teks sastra Senjang, pemain, penonton, dan tempat pertunjukan.

\section{Pembahasan}

\section{A. Perkembangan Kesenian Senjang Di Kota Sekayu}

Bicara Asal mula tradisi Senjang memang sulit teridentifikasikan dengan pasti, menurut Yulia (wawancara 12 Januari 2020 di Sekayu) menjelaskan seni tutur Senjang merupakan kesenian khas masyarakat Musi Banyuasin yang awalnya berkembang di salah satu kecamatan yang ada di wilayah Kabupaten Musi Banyuasin, yaitu Kecamatan Sungai keruh. Di Kecamatan inilah pertamakali kesenian Senjang dipertunjukan, kemudian dikembangkan ke Kecamatan Babat-toman, Kecamatan Sanga Desa, dan Kecamatan Sekayu. Namun seiring perkembanganya tiap-tiap daerah di Musi Banyuasin memiliki khas dan gaya tersendiri dalam penyampaiannya.

Terkait dengan sejarah kesenian Senjang di Musi Banyuasin, Peeters dalam tulisanya yang berjudul "Kaum 
Tuo - Kaum Mudo Perubahan Relegius di Palembang 1821-1942 (dalam Apriadi, 2018: 6) menjelaskan sebagai berikut:

"Senjang lahir dari hasil dari kebiasaan masyarakat yang hidup didaerah Talang. Penduduk didaerah talang cenderung memiliki karakteristik yang sangat mencolok mulai dari cara berbicara, adat istiadat dan juga tata cara hidup mereka sehari-hari. Dari daerah talang Senjang baru menyebar ke daerah Sekayu dan sekitarnya karena Sekayu merupakan daerah renah. Daerah talang yang disebutkan di dalam ini adalah daerah sungai Keruh, daerah inilah Senjang pertama kali lahir dikarnakan dilihat dari topografi daerahnya daerah sungai Keruh merupakan daerah yang berbukit sehingga daerah sungai Keruh merupakan daerah yang kering dan tidak adanya rawa-rawa dan juga daerah talang merupakan daerah yang tidak di pengaruhi oleh pasang surut air sungai sehingga daerah ini mempunyai karakteristik tanah kering dan berkerikil. Sedangkan daerah Sekayu, Babat Toman dan sekitarnya merupakan daerah renah karena dearah ini sangat di pengaruhi oleh pasang surut air sungai sehingga masyarakat pendukungnyapun bermata pencaharian sebagai nelayan dan petani. Perubahan budaya terjadi ketika tanah renah kelebihan bahan pangan menyebabkan adanya kontak dagang dengan dunia luar. Ketika masyarakat asli renah memiliki tanah yang subur mereka tidak lagi menerima budaya dari luar ketika orang talang bermigrasi ke daerah renah terjadinya bentuk komunikasi yang lebih kuat sehingga Senjang pun berkembang menjadi sarana berkomunikasi antara masyarakat renah dan talang. Awalnya petama kali Senjang masuk kedaerah renah ketika masyarakat talang menyampaikan Senjang di balai desa lewat sistem seperti pantun sehingga masyarakat renahpun ikut berSenjang sehingga Senjang menjadi sebuah hiburan baru di masyarakat renah sehingga budaya renah di Musi Banyuasin sedikit mengalami perubahan akibatnya masyarakat Musi Banyuasin memiliki tipikal masyarakat talang dikarnakan komunikasi antara masyarakat renah dan talang (Peeters, 1997:38)"

Senjang adalalah pertunjukan musik vokal yang berisikan teks-teks sastra daerah (sastra lisan jenis talibun) yang diiringi oleh instrumen musik pengiring. Pada awal perkembanganya, penyajian kesenian Senjang diiringi oleh musik tanjidor. Namun, Seiring dengan perkembangan zaman, dewasa ini, musik pengiring Senjang telah digantikan dengan alat musik keyboard/organ digital atau "orgen tunggal". Hal ini terjadi karena langkanya pemain tanjidor, akibat menurunya eksistensi kesenian ini di di Sekayu.
Menurut Yulia, "istilah atau penamaan kesenian Senjang oleh masyarakat merujuk pada konsep pertunjukannya, yakni antara peSenjang yang mendendangkan syair tidak seiring atau berbarengan dengan musik atau instrumen musik pengiringnya, atau dalam penyajian Senjang vokal dan instrument musik dimainkan secara bergantian" (wawancara, 12 januari 2020).

Secara tradisi, Senjang biasanya dipertunjukan sebagai hiburan pada acara-acara yang bersifat seremonial seperti acara perkawinan, peresmian lembaga, penyambutan tamu agung, festifal budaya dan lain-lain. Dalam hal ini Senjang dapat menyatukan masyarakat, menghubungkan antara orang tua dengan generasi muda atau antara masyarakat dengan Pemerintah. Disamping itu, dalam konteksnya Senjang juga berfumgsi sebagai komunikasi sosial, seperti penyampaian aspirasi dan pesan-pesan yang berisikan nasehat, kritik, pendidikan,dan ungkapan kegembiraan.

Terkait dengan hal di atas Yulia menambahkan "istilah Senjang mengandung filosofi tersendiri dalam masyarakat Musi Banyuasin, yang mana Senjang dapat di pahami sebagai media penyampaian aspirasi karena keSenjangan (ketidaksejajaran, keseimbangan) yang terjadi didalam masyarakat, seperti konsep hidup dengan realitas, keSenjangan sosial, pendidikan, agama dan lainlain. oleh sebab itu teks Senjang atau syair Senjang cenderung bersifat sindiran, kristis dan nasehat. Walaupun dalam perkembangangnya Senjang disesuaikan dengan konteks acara tertentu" (wawancara, 12 Januari 2020 di Sekayu).

Kesenian Senjang pada masyarakat Musi Banyuasin sudah diwariskan secara turun temurun sejak dahulu dan masih eksis hingga sekarang. Sejalan dengan hal tersebut, Busriyanto (Kabid pariwisata kota Sekayu) menjelaskan,

"kesenian Senjang merupakan kesenian yang cukup populer di Musi Banyuasin khususnya di kota Sekayu, hal ini terlihat dari setiap acara-acara hiburan dan upacara (khususnya perkawinan) di kota Sekayu saat itu sering dimeriahkan dengan kesenian ini. Begitu pentingya kesenian Senjang bagi masyarakat, sehingga setiap acara dan upacara menurut masyarakatnya kurang lengkap kalau belum menghadirkan kesenian Senjang (wawancara, 5 Januari 2020)".

Perkembangan kesenian Senjang saat ini di juga dukung oleh peran pemerintah Musi Banyuasin dalam mempromosikan seni budaya daerah, salah satunya dengan mengadakan festiva randik yang diadakan setiap tahunnya, festival ini memperkenalkan seni budaya yang ada di Musi Banyuasin seperti tari, musik, pakaian adat, kuliner, dan kesenian Senjang. Salah satu kegiatan dari festifal randik adalah diadakanya lomba Senjang sekabupaten Musi Banyuasin. Sehingga banyak kelompok dan sanggar seni di berbagai kecamatan di musi banyuasin yang melestarikan kesenian Senjang)".

Berdasarkan data dari Dinas Kebudayaan Kabupaten Musi Banyuasin, peSenjang-peSenjang senior 
di Kabupaten Musi Banyuasin yang masih eksis saat ini antara lain Majening (70 tahun), Siti Hawa (65 tahun) dari Sanga Desa, Tarmizi Sidik dari desa Lumpatan, Amrullah dari dusun 3 Desa Muara Teladan, Yulia (50 tahun) di kota Sekayu, dan Sulaiman dari Kecematan Lais.

Pelestarian kesenian Senjang ini, disamping dilakukan oleh pemerintah dan sanggar seni, masyarakat juga ikut andil dalam melestarikanya yakni dengan cara selalu menggunakan kesenian ini disetiap upacara dan acara keramaian. Makna dan nilai yang terkandung pada Senjang antara lain berisi nasehat, ajaran moral, kritik, yang bersifat edukatif dan sangat berguna dalam kehidupan masyarakat sehari-hari. Nasehat tersebut berfungsi menyadarkan dan mengontrol orang-orang yang mendengar Senjang agar tidak melakukan hal-hal di luar norma-norma masyarakat.

\section{B. Bentuk Penyajian Kesenian Senjang Dalam Konteks Acara Hiburan Dan Seremonial Di Kota Sekayu}

Bentuk dalam seni pertunjukan merupakan kesatuan dari unsur-unsur yang terdapat didalam sebuah karya seni untuk diperlihatkan kepada khalayak ramai. Setiap pertunjukan seni baik itu tari, musik, dan teater pasti ada bentuk pertunjukan di dalam pementasan tersebut, di mana dalam pertunjukannya ada aspek-aspek yang mempunyai hubungan satu sama lain sehingga membuat penyajian menjadi menarik. Membahas bentuk seni berarti juga membahas struktur dari karya seni tersebut, terkait dengan itu Djelantik mengatakan bahwa struktur atau susunan dari suatau karya seni adalah aspek yang menyangkut keseluruhan dari karya itu, dan meliputi juga peranan dari masing-masing bagian dalam keseluruhan. Kata struktur mengandung arti bahwa dalam karya seni itu terdapat pengorganisasian, pengaturan, dalam hubungan tertentu antara bagian dari keseluruhan (1999: 37).

Selanjutnya Djelantik (1999: 73) menjelaskan penyajian yaitu bagaimana kesenian itu disugukan kepada yang menyaksikan, penonton, para pengamat, pembaca, pendengar, khalayak pada umumnya. begitu juga yang terjadi pada pementasan Senjang di kota Sekayu Kabupaten Musi Banyuasin. Maka dalam bahsan ini akan diuraikan bentuk Penyajian Kesenian Senjang yang meliputi susunan penyajian Senjang, teks syair Senjang, musik vokal dan intrument, aspek pemain, penonton, dan tempat pertunjukan.

\section{1) Susunan Penyajian Senjang}

Secara tradisi dari aspek waktu tidak aturan yang baku yang mengatur kapan Senjang mulai di mainkan dalam konteks acara/ upacara dalam masyarakat kota Sekayu. Biasanya pertunjukan baik pada konteks hiburan masyarakat dan acara seremonial seperti pada upacara perkawinan di mulai di sesuaikan dengan jadwal yang telah di tentukan oleh panitia acara, dan biasanya di mainkan pada sesi hiburan. Begitu juga halnya dengan durasi waktu pertunjukannya, juga mengikuti dengan jadwal dalam konteks acara tersebut atau tergantung dengan permintaan tuan rumah, biasanya durasi pertunjukan Senjang dimainakan sekitar lebih kurang 1525 menit.

Selanjutnya dari aspek urutan dalam penyajian materinya, kesenian Senjang adalah satu kesatuan materi yang terdiri dari instrument musik, musik vokal (syair sastra Senjang), dan tarian. Dalam proses penyajianya, kesenian Senjang memiliki konsep penyajian yang khas dan berbeda dengan konsep penyajian musik dan vokal secara umum di nusantara yang materinya di sajikan secara bersamaan. Akan tetapi pada kesenian Senjang antara instrument musik dengan musik vokal syair Senjang dimainkan secara bergantin atau selang seling.

Penyajian Senjang diawali dengan permainan melodi instrumen musik (keyboard) sebanyak 6 bar dan berhenti, selanjutnya langsung dilantunkan musik vokal Senjang dengan satu buah syair Senjang (tanpa iringan instrumen musik) dan berhenti. Begitu selanjutnya penyajian instrumen musik dan vokal disajikan secara secara bergantian dengan pola yang sama, namun penyajiannya di akhiri dengan permainan melodi instrument musik.

Pada saat pertunjukanya, terdapat gerakan tarian sederhana yang dilakukan oleh pelantun vokal Senjang, peSenjang biasanya menari dengan mengayunkan tangan dan kaki (seperti gerakan melenggang pada tari melayu) dengan melenggokan badan kekiri dan kanan. Tarian ini dilakukan pada saat permainan instrumen musik, dan Gerakanya disesuaikan dengan ritme musik tersebut. sedangkan pada saat melantunkan vokal tidak dilakukan dengan gerakan tari.

\section{2) Aspek Teks sastra Senjang}

Senjang adalah bentuk sastra lisan khas Musi Banyuasin yang penyajianya dilantunkan dengan irama tertentu. Adapun sastra lisan Senjang adalah puisi lama dengan jenis pantun dan talibun. Biasanya secara tradisi sering disajikan jenis talibun 5 baris, 6 baris, dan 10 baris yang terdiri atas sampiran dan isi dengan berbagai pola irama/sajak. Disamping itu sastra Senjang juga di sajikan dalam bentuk pantun 4 baris yang terdiri dari 2 sampiran dan dua isi, namun dalam penyajian Senjang jenis talibun lebih sering dipakai dari pada pantun.

Menurut kamus KBBI "Talibun adalah bentuk puisi lama dalam kesusastraan Indonesia (Melayu) yang jumlah barisnya lebih dari 4 , biasanya antara $16-20$, serta mempunyai persamaan bunyi pada akhir baris (ada juga seperti pantun, dengan jumlah baris genap, seperti 6, 8, atau 12 baris)" (https://kbbi.web.id/talibun). Sedangkan "Pantun adalah bentuk puisi Indonesia (Melayu), tiap bait (kuplet) biasanya terdiri atas empat baris yang bersajak (a-b-a-b), tiap larik biasanya terdiri atas empat kata, baris pertama dan baris kedua biasanya untuk tumpuan (sampiran) saja dan baris ketiga dan keempat merupakan isi; 2 peribahasa sindiran" (https://kbbi.web.id/pantun).

Secara umum di Musi Banyuasin terdapat berbagai jenis sastra Senjang menurut fungsinya, diantaranya 
adalah Senjang nasehat, pendidikan, sindiran dan kritik, percintaan, ungkapan perasaan dll. Namun materi atau isi sastra Senjang pada saat pertunjukannya disesuaikan dengan konteks acara dan fenomena yang terjadi saat itu. Misalnya pada acara pernikahan biasanya dalam isi Senjang terdapat bagian yang memuji kebaikan mempelai, memberi nasehat dll.

Berikut contoh teks sastra Senjang berdaarkan fungsinya.

\section{a. Senjang Nasehat}

Senjang nasehat adalah "Senjang" yang berisikan nasehat-nasehat moral, akhlak, rohani, sebagai pedoman dalam menjalankan kehidupan sehai-hari. Contoh:

\begin{tabular}{|l|l|}
\hline \multicolumn{1}{|c|}{ Teks Senjang } & \multicolumn{1}{c|}{ Bahasa Indonesia } \\
\hline $\begin{array}{l}\text { Pesan kami ngen para pejabat } \\
\text { Nak banyak-nakyak nian ngucap } \\
\text { Angken dak tejadi suap menyuap } \\
\text { Supayo idop pacak selamat } \\
\text { Dari dunia sampai akherat }\end{array}$ & $\begin{array}{l}\text { Pesan kami kepada para pejabat } \\
\text { harus banyak-banyak istigfar } \\
\text { supaya tidak terjadi suap- } \\
\text { menyuap } \\
\text { supaya hidup bisa selamat } \\
\text { dari dunia hingga akhirat }\end{array}$ \\
$\begin{array}{l}\text { sebatang bulu sampaikan kain } \\
\text { tiangnye kebat dengan tali } \\
\text { sapulu macam gawe nyang lain } \\
\text { ngaji semayang jangan lali }\end{array}$ & $\begin{array}{l}\text { sebatang bambu jemuran kain' } \\
\text { tiangnya diikat dengan tali' }\end{array}$ \\
& 'sepuluh macam kerja yang lain' \\
& 'ngaji sembahyang jangan lupa' \\
\hline
\end{tabular}

\section{b. Senjang Sindiran}

sindiran adalah perkataan (gambar dan sebagainya) yang bermaksud menyindir orang; celaan (ejekan dan sebagainya) yang tidak langsung (https://kbbi.web.id/sindir). Selanjutnya sindiran juga diartikan sajak yang mengandung pernyataan yang menimbulkan tawa, tetapi juga dapat menimbulkan kemarahan, isinya protes sosial dengan cara mengejek habis-habisan; (https://kbbi.web.id/sajak/sindiran).

Senjang sindiran adalah "Senjang" yang berisikan sindiran kepada seseorang. Biasanya ditujukan pada kondisi sosial secara umum yang menyimpang, masalah keadilan, pemerintahan, dll. Contoh Senjang sindiran.

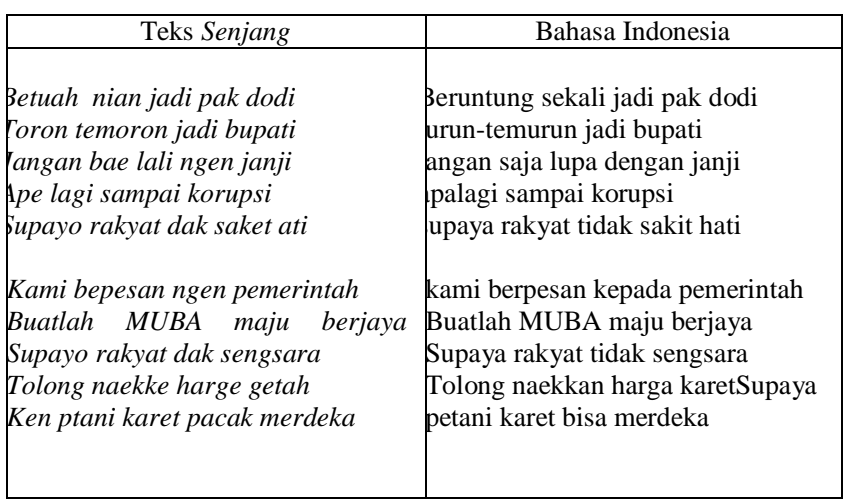

\section{c. Senjang Ungkapan Perasaan}

Senjang ungkapan perasaan adalah "Senjang" yang berisikan ungkapan perasaan,seperti rasa cinta, rasa sedih, dan rasa kecewa. Contoh Senjang ungkapan perasaan.

\begin{tabular}{|l|l|}
\hline \multicolumn{1}{|c|}{ Teks Senjang } & \multicolumn{1}{c|}{ Bahasa Indonesia } \\
\hline $\begin{array}{l}\text { pucuq pauh selaghi pauh } \\
\text { buanye masak dimakan ulat } \\
\text { kuyung jauh adiklah Jauh } \\
\text { kitek batemu dalam sughat }\end{array}$ & $\begin{array}{l}\text { pucuk pauh daun kuning pauh' } \\
\text { 'buahnya masak dimakan ulat' }\end{array}$ \\
& 'kakak jauh adiklah jauh' \\
& 'kita bertemu dalam surat' \\
\hline
\end{tabular}

\section{Struktur Penyajian Sastra Senjang}

Struktur penyajian sastra Senjang dalam pertunjukannya terdiri atas tiga bagian yakni; pembuka, adalah bagian awal dimulainya Senjang yang berisi ucapan salam dan meminta izin untuk memulai Senjang. Bagian Isi, yakni bagian penyajian isi Senjang yang terdiri dari berbagai materi Senjang yang disesuaikan dengan konteks acara. Dan Bagian penutup, berisi permohonan maaf dan izin undur diri. Adapun contoh struktur pembagian sastra Senjang sebagai berikut :

\begin{tabular}{|c|c|}
\hline Teks Senjang & Bahasa Indonesia \\
\hline $\begin{array}{l}\text { 1. Bagian pembuka Senjang } \\
\text { Cobo-cobo maen gelumbang } \\
\text { Entahke padi entah dedek } \\
\text { Bemban burung pulo lalang } \\
\text { Untuk bahan muat keranjang } \\
\text { Cobo-cobo kami nak Senjang } \\
\text { Entahke pacak entah dak } \\
\text { Kepalang kami telanjur Senjang } \\
\text { Kalu salah tolong maafkan. }\end{array}$ & $\begin{array}{l}\text { Coba-coba main gelumbang } \\
\text { Entahkah padi entah dedak } \\
\text { Bemban burung pulau lalang } \\
\text { Untuk bahan pembuat keranjang } \\
\text { Coba-coba kami ingin Senjang } \\
\text { Entah bisa entah tidak } \\
\text { Kepalang kami terlanjur Senjang } \\
\text { Kalau salah tolong maafkan }\end{array}$ \\
\hline $\begin{array}{l}\text {. Bagian isi Senjang } \\
\text { Kalu adek ke Pelembang } \\
\text { Jangan lali ngunde tajur } \\
\text { Tajur pasang di Sekanak } \\
\text { Bawa batang buah benono } \\
\text { Kalo adek bajo linjang } \\
\text { Jangan sampai talanjur } \\
\text { Kalo rusak lagi budak } \\
\text { Alamat idup dak sampurno. } \\
\text { Petang petang bosek ke taman } \\
\text { Bosek ke taman dengen kule } \\
\text { Sambel meli gule-gule } \\
\text { Meli gule di warung pak budi } \\
\text { Meli pulek di warung bek cici } \\
\text { Ikaklah idop di akher zaman } \\
\text { galek galek serbe nyembele } \\
\text { kecik-kecik lah pacak bekule } \\
\text { ikaklah oleh teknologi canggih } \\
\text { sangkan budak gancang belaki }\end{array}$ & $\begin{array}{l}\text { Kalau adik ke Palembang } \\
\text { Jangan lupa membawa tajur } \\
\text { Tajur pasang di Sekanak } \\
\text { Bawah pohon buah benunu } \\
\text { Kalau adik belajar pacaran } \\
\text { Jangan sampai terlanjur } \\
\text { Kalau ternoda sejak muda } \\
\text { Alamat hidup tidak sempurna } \\
\text { Sore-sore main ke taman } \\
\text { Main ke taman bersama pacar } \\
\text { Sambil beli gula-gula } \\
\text { Beli gula di warung pak budi } \\
\text { Beli juga di warung tante cici } \\
\text { Inilah hidup di akhir zaman } \\
\text { Segala sesuatu serba aneh } \\
\text { kecil-kecil sudah bisa pacaran } \\
\text { inilah akibat teknologi canggih } \\
\text { makanya anak kecil cepat nikah }\end{array}$ \\
\hline
\end{tabular}




\begin{tabular}{|l|l|}
\hline 3. Bagian penutup Senjang & \\
Kalu nak pegi ke Karang Waru & Kalau akan pergi ke Karang Waru \\
Singgah tegal di jeramba pogok & Singgah sejenak di Jembatan pogok \\
Tengah jalan ke Rantau Kasih & Tengah jalan ke Rantau Kasih \\
Nak pegi ke dusun Ugulak & Hendak pergi ke desa ulak \\
Kami Senjang berenti dulu & Kami berSenjang berhenti dulu \\
Adat kerene abis pokok & Karena habis persediaan \\
Kami ucapke terime kaseh & Kami ucapkan terima kasih \\
Maafke bae kate yang salah. & Mohon maafkan kata yang salah \\
& \\
\hline
\end{tabular}

\section{3) Musik Senjang}

Pada kesenian Senjang terdapat dua aspek musik yakni musik instrumen sebagai pengiring dan musik vokal sastra Senjang. Akan tetapi dalam penyajianya, antara musik instrument dengan musik vokal sastra Senjang dimainkan secara bergantin atau selang seling. Urutan penyajian Senjang yakni diawali dengan permainan melodi instrumen musik (keyboard) sebanyak 6 bar dan berhenti, selanjutnya langsung dilantunkan musik vokal Senjang dengan satu buah syair Senjang (tanpa iringan instrumen musik) dan berhenti. Begitu selanjutnya penyajian instrumen musik dan vokal disajikan secara secara bergantian dengan pola yang sama, namun penyajiannya di akhiri dengan permainan melodi instrument musik.

\section{a. Musik Instrumen}

Ada dua bentuk penyajian iringan musik Senjang, pertama yakni dimainkan secara ansambel, biasanya pada zaman dahulu diiringi dengan ansambel tanjidor, karena pemain tanjidor sanggat langka saat ini maka digantikan dengan band. Kedua dimainkan secara tunggal, yang paling sering dibawakan melalui alat musik Organ Tunggal (sejenis Keyboard piano digital yang dapat memainkan berbagai progam musik), biasanya permainan melodi diiringi dengan style program musik dangdut. Berikut bentuk melodi instrumen musik Senjang.

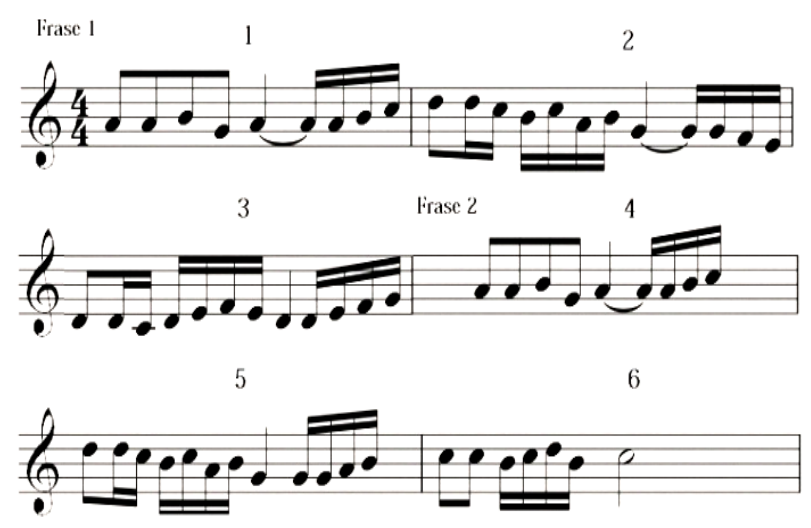

Gambar 1. Melodi Musik Senjang

(Dok: Transkripsi Irfan Kurniawan, 2020)
Musik vokal pada kesenian Senjang bersifat free ritme (tidak ada sukat). Berikut bentuk melodi vokal Senjang.

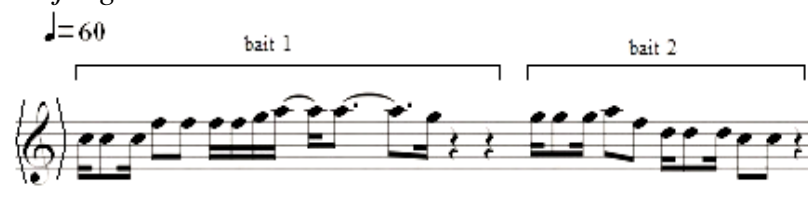

kv yung ku jo ni ai hebat ni- - an _. me-ro-jo nga nak ngang-kat sedakah

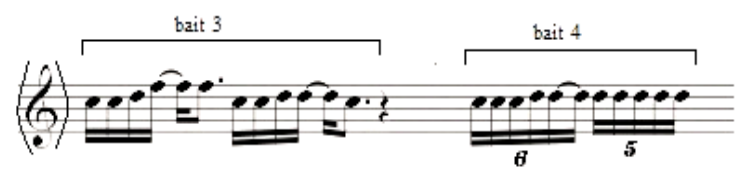

ngum-pul-ke-sgale sa-nak-kluar-ge ngundang pencramah daghi plembang

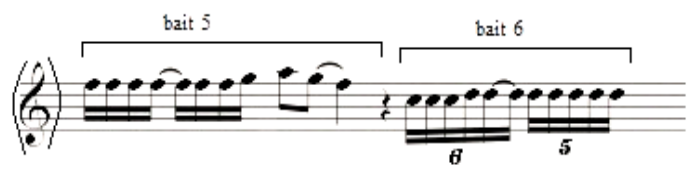

lwrah ade-serta rom-bo-ngan pejabat camat da ketinggalan

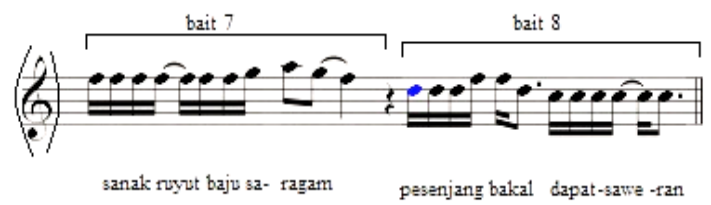

Gambar 2. Melodi Vokal Senjang

(Dok: Transkripsi Irfan Kurniawan, 2020)

\section{4) Pemain}

Pemain dalam pertunjukan Senjang terdiri dari pemain instrumen musik dan peSenjang (penutur vokal Senjang). Pemain musik bisa perankan oleh satu orang yang biasanya mamainkan instrumen keyboard (orgen tunggal), dan dapat juga di lakukan secara kelompok atau ansambel seperti tanjidor dan band.

Selanjutnya dari aspek pemain vokal Senjang/ peSenjang secara tradisi ada dua bentuk penyajian pertunjukanya yakni' Pertama, disajikan oleh satu orang pemain (biasanya perempuan), Kedua, disajikan oleh dua orang pemain (biasanya 2 orang perempuan atau bisa juga berpasangan laki-laki dan perempuan), dimana dalam penyajian sastra Senjang dilakukan secara bergantian (biasanya untuk teks isi dan sampiran 5 baris), disamping itu juga dilakukan dengan cara satu orang menuturkan sampiran dan satunya menuturkan isi (biasanya untuk teks sampiran dan isi berjumlah 8-10 baris).

Busana atau pakaian yang digunakan pemain/ peSenjang pada pertunjukan Senjang, biasanya menggunakan pakaian adat Musi Banyausin yakni untuk perempuan memakai baju kebaya lengkap dengan aksesoris, dan baju koko atau bisa diganti dengan jas untuk laki-laki, serta menggunakan tanjak di kepala.

\section{b. Musik Vokal}




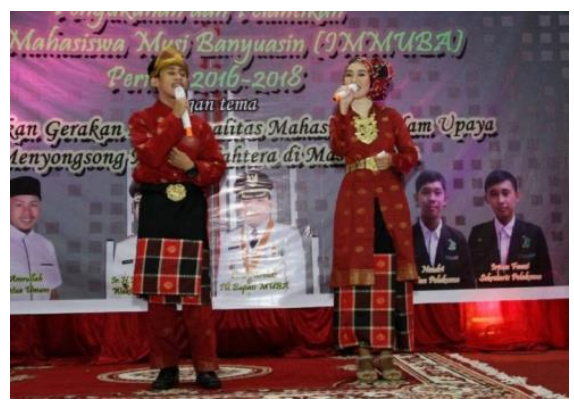

Gambar 3. Bentuk penyajian Senjang yang dibawakan 2 orang berpasangan

(Sumber: Antero Sumsel, 2019)

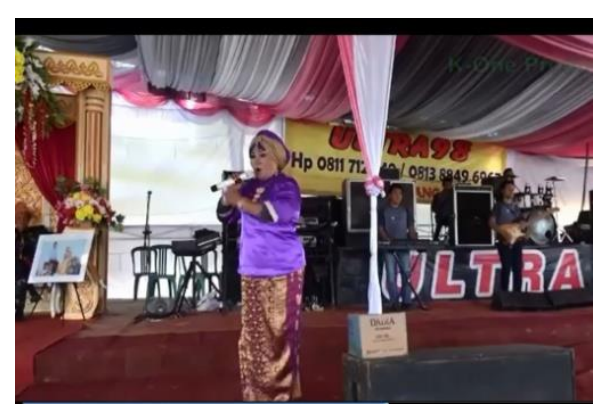

Gambar 4. Bentuk Penyajian Senjang yang di bawakan oleh satu orang peSenjang

(Sumber: K-One Production, 2017)

Terkait dengan penyajian Senjang, dalam buku yang ditulis oleh Ghafar yang berjudul "Struktur Sastra Lisan Musi"(Ghafar, 1989: 20) menjelaskan gaya penyajian Senjang pada zaman dulu sebagai berikut:

"Senjang ialah sejenis pantun bersahut yang dituturkan oleh dua orang gadis sambil menari. Gadis yang melakukan Senjang itu biasanya adalah gadis piliban karena sambil menari sekaligus menciptakan pantun itu. Puisi yang dinyanyikan itu berisi sindiran. Dua orang gadis pilihan itu berSenjang selama lebih dari dua jam. Mereka berusaha saling mengalahkan lawannya."

Dari kutipan diatas tentang gaya penyajian Senjang seperti yang di jelaskan oleh Ghafar tersebut, dari hasil pengamatan dan wawancara dengan narasumber, penyajian seperti itu tidak ditemui lagi dalam konteks pertunjukanya pada masyarakat Musi Banyuasin khusunya kota Sekayu.

Pemain Senjang idealnya saat pertunjukan menciptakan sastra Senjangnya secara spontan, sehingga tema yang disampaikan disesuaikan dengan suasana yang dihadapinya. Akan tetapi, sekarang kemampuan seniman Senjang yang seperti itu sudah sangat langka. Saat ini biasanya peSenjang menyiapkan syair Senjangnya jauh hari sebelum pertunjukan dilaksanakan, bahkan sering peSenjang membawa catatan/ teks saat pertunjukan.
Berdasarkan wawancara dengan bapak Busriyanto, ia menjelaskan bahwa tidak mudah untuk menjadi peSenjang yang ideal seperti zaman dahulu, menurutnya hal itu dipengaruhi oleh beberapa hal, pertama; disebabkan oleh kondisi sosial budaya dan komunikasi masyarakat saat ini sudah banyak berubah, tidak seperti zaman dulu dimana eksistensi sastra lisan dalam komunikasi sehari-hari sering digunakan. Kedua, ketekunan dan intensitas seseorang dalam mempelajari sastra Senjang, karena saat ini tidak banyak generasi muda yang benar-benar menekuni kesenian Senjang ini, sehingga kemampuanya tidak maksimal, seperti halnya melihat teks saat pertunjukan. Disamping itu juga karena generasi muda sekarang sanagat jarang yang ingin berprofesi sebagai peSenjang. Biasanya hanya dilakukan pada even-even tertentu saja, seperti festival budaya, dll (wawancara, 5 Januari 2020)

Ditinjau dari aspek kesenimanannya, untuk menjadi penutur Senjang yang ideal seorang peSenjang dituntut harus memiliki pengalaman dan pengetahuan yang luas terutama dalam hal adat, budaya, agama, dan kehidupan sosial. Sehingga seorang peSenjang bisa menuturkan Senjangnya dengan spontan yang berisikan berupa nasehat, pendidikan, agama, sosial, budaya dan lain sebagainya.

Selanjutnya untuk menggunakan jasa pertunjukan kesenian Senjang, pemain Senjang sebelum pertunjukan terlebih dahulu di undang oleh pihak yang mengadakan acara, biasanya pihak yang mengundang menyampaikan jenis acara yang akan dihibur dengan pertunjukan Senjang. Hal ini dilakukan agar pemain Senjang terlebih dahulu dapat mempersiapkan diri dan materi yang akan di tampilkan nantinya yang sesuai dengan konteks dan permintaan dari pihak yang menyelanggarakn acara.

Secara tradisi tidak ada patokan harga atau honor bagi pemain Senjang, biasanya dari pihak penyelenggara acara yang memberikan amplop berisikan uang kapada pemain Senjang. Namun akhir-akhir ini pemain Senjang di kota Sekayu telah di hargai secara profesional dengan harga yang variatif tergantung kepada kualitas dan tingkat kepopuleran peSenjang. Hal tersebut terjadi karena saat ini banyak peSenjang yang tergabung dalam manajemen komunitas sanggar modern.

\section{5) Penonton}

Senjang adalah salah satu bentuk media komunikasi budaya yang dapat menghubungkan berbagai lapisan masyarakat, seperti antara orang tua dengan generasi muda, atau dapat juga antara masyarakat dengan Pemerintah di dalam bentuk penyampaian aspirasi yang berupa nasihat, kritik, pendidikan, serta ungkapan rasa gembira.

Walaupun materi Senjang sangat kompeks terkait dengan moral, pendidikan, kritik dll, akan tetapi dalam konsep penyajianya Senjang tetap dibawakan dengan cara sidiran yang bersifat menghibur, kocak/ jenaka, sehingga orang menyaksikan pertunjukanyasangat antusias dan tidak merasa bosan. 
Para penonton Senjang biasanya adalah para tamu undangan dalam suatu hajatan/ perhelatan perkawinan, acara pemerintahan dll, disamping itu juga para penonton yang datang pada acara keramaian lainya, seperti festival budaya, hut kemerdekaan dan sebagainya. Pada dasarnya pertunjukan Senjang dapat dinikmati oleh berbagai kalangan dan usia, namun lebih didominasi oleh kalangan dewasa keatas, karena lebih banyak pengalaman hidup sehingga dapat memahami isi sastra Senjang dengan baik daripada anak remaja kebawah.

Pada saat penyajian Senjang, peSenjang dan penonton sangat interaktif, hal itu dapat dilihat dari berbagai respon penonton saat pertunjukan berlangsung, seperti berteriak, tertawa, dan bahkan ada yang merasa malu ketika peSenjang melakukan sindiran terhadap penonton tertentu, seperti ungkapan 'besoklah bosung daghi kepalo' "besarlah perut dari kepala" (sindiran kepada orang yang mengutamakan kehendak perut saja, tanpa berpikir atau bekerja terlebih dahulu ), atau menyindir para tamu pejabat agar memberikan uang tips (saweran) kepada peSenjang, seperti contoh transkrip Senjang yang di bawakan oleh ibuk Yulia (kopek Yul) berikut:

\section{Teks Senjang:}

Kuyungku ini hai hebat nian

Merojo nga nak ngangkat sedekah

Ngumpulke gale sanak kelurge

Ngundang pencramah daghi plembang

Lurah ade seta rombongan

Pejabat camat dak ketinggalan

Sanak ruyut baju seragam

Yang Senjang bakal dapet saweran

Bahasa Indonesia:

sungguh hebat kakak ku ini abis-habisan mengadakan hajatan mengumpulkan sanak keluarga

mengundang pencera

mah dari palembang

lurah ada serta rombonga

pejabat camat tidak ketinggalan

sanak famili buju seragam

peSenjang bakal dapat saweran

Biasanya kalau penampilan peSenjang sangat menghibur dan kocak, para penonton memberikan semacam uang tips/saweran kepada peSenjang (ada juga yang disediakan kotak di depan peSenjang untuk memasukan uang saweran tersebut) sebagai bentuk apresiasi.

\section{6) Tempat pertunjukan}

Dalam pertunjukan kesenian Senjang, tidak ada ketentuan baku dari aspek tempat pertunjukan. Biasanya pertunjukan pada hajatan perkawinan dan acara keramaian lainya di kota Sekayu permainan Senjang di tampilkan diatas panggung dengan penonton menghadap satu arah pada pemain. Adapun tempat pertunjukan Senjang telah dipersiapkan sebelumnya oleh panitia acara. Berikut sketsa tempat pertunjukan Kesenian Senjang.
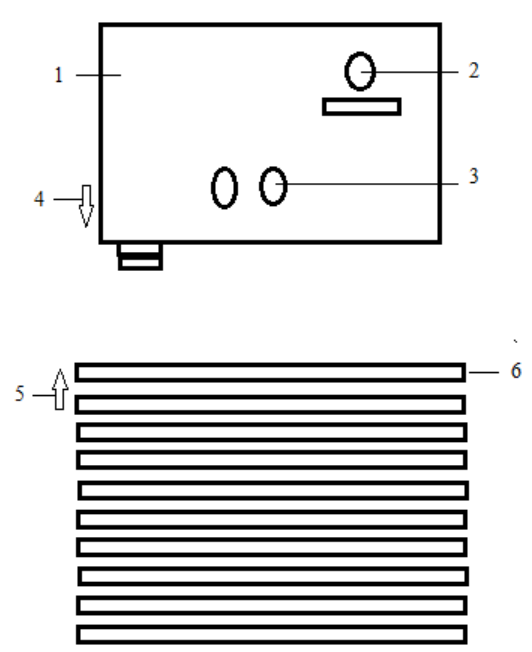

Gambar 5. Sketsa Tempat Pertunjukan (Juli Saputra, 2020)

Ket: $\quad$ 1. Panggung

2. Posisi Pemusik

3. Posisi PeSenjang

4. Arah Hadap Panggung

5. Arah Hadap Penonton

6. Posisi/ tempat duduk Penonton

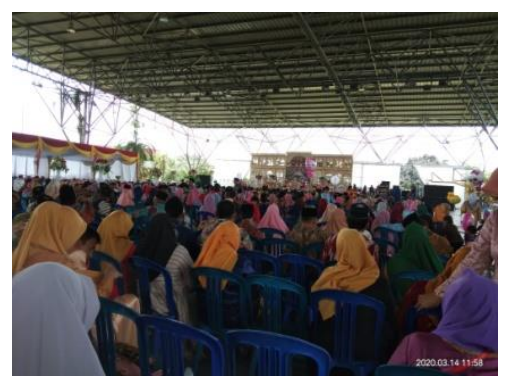

Gambar 6. Pertunjukan Kesenian Senjang Pada Acara Hajatan Perkawinan (Juli Saputra, 2020)

\section{Kesimpulan}

Berdasarkan Hasil Penelitian, dapat diuraikan permasalahan bentuk penyajian kesenian Senjang di kota Sekayu yang meliputi; aspek teks sastra Senjang, urutan penyajian Senjang, musik vokal dan instrumen, aspek pemain, penonton, dan tempat pertunjukan.

Dari aspek teks penyajianya Senjang adalah bentuk sastra lisan khas Musi Banyuasin yang penyajianya dilantunkan dengan irama tertentu. Adapun sastra lisan Senjang adalah puisi lama dengan jenis pantun dan talibun. Secara umum di Musi Banyuasin terdapat berbagai jenis sastra Senjang menurut fungsinya, diantaranya adalah Senjang nasehat, 
pendidikan, sindiran dan kritik, percintaan, ungkapan perasaan dll.

Pada kesenian Senjang terdapat dua aspek musik yakni musik instrumen sebagai pengiring dan musik vokal sastra Senjang. Akan tetapi dalam penyajianya, antara musik instrument dengan musik vokal sastra Senjang dimainkan secara bergantin atau selang seling. Pada awal perkembanganya, penyajian kesenian Senjang diiringi oleh musik tanjidor. Namun, Seiring dengan perkembangan zaman dan langkanya pemain tanjidor, sehingga musik pengiring Senjang digantikan dengan alat musik keyboard/organ digital atau "orgen tunggal".

Pemain vokal Senjang/ peSenjang secara tradisi ada dua bentuk penyajian pertunjukanya yakni' Pertama, disajikan oleh satu orang pemain (biasanya perempuan), Kedua, disajikan oleh dua orang pemain (biasanya 2 orang perempuan atau bisa juga berpasangan laki-laki dan perempuan).

Pada saat pertunjukan, penonton sangat interaktif dengan peSenjang, hal itu dapat dilihat dari berbagai respon penonton saat peSenjang melantunkan sastra senjnag dengan sidiran saat pertunjukan berlangsung, seperti berteriak, tertawa, dan berbagai ekspresi lainya. Biasanya kalau penampilan peSenjang sangat menghibur dan kocak, para penonton memberikan semacam uang tips/saweran kepada peSenjang.

Biasanya pertunjukan pada hajatan perkawinan dan acara keramaian lainya di kota Sekayu permainan Senjang di tampilkan diatas panggung dengan penonton menghadap satu arah pada pemain. Tempat pertunjukan Senjang telah dipersiapkan sebelumnya oleh panitia acara.

\section{Daftar Pustaka}

Apriadi, B., \& Chairunisa, E. D. (2018). Senjang: Sejarah Tradisi Lisan Masyarakat Musi Banyuasin. Kalpataru Jurnal Sejarah dan Pembelajaran Sejarah, 4(2), 124-128.

Djelantik, A.A.M. 1999. Estetika sebuah pengantar. Bandung Masyarakat Seni Indonesia.

Gaffar, Zainal Abidin. 1989. Struktur Sastra Lisan Musi. Jakarta: Depdikbud.

Moleong, Lexy J. 2011. Metodologi Penelitian Kualitatif. Cet:24. Bandung: Remaja Rosdakarya.

Sukma, Irawan, 2015. Keberadaan Kesenian Senjang Pada Masyarakat Kabupaten Musi Banyuasin Sumatera Selatan.. Tesis. Institut Seni Indonesia Surakarta.

https://kbbi.web.id/. Diakses tanggal 09/01/2020 